International Journal of Social Science And Human Research

ISSN(print): 2644-0679, ISSN(online): 2644-0695

Volume 05 Issue 01 January 2022

DOI: 10.47191/ijsshr/v5-i1-02, Impact factor-5.586

Page No: $10-14$

\title{
Implementation of Work from Home Institutional of Indonesian Migrant Workers Protection Agency (BP2MI) in the Second Year of the Covid-19 Pandemic towards Society 5.0
}

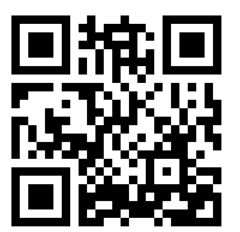

\author{
Ari Nurhayati ${ }^{1}$, Nrangwesthi Widyaningrum ${ }^{2}$, Hikmat Zakky Almubaroq ${ }^{3}$ \\ ${ }^{1}$ Department of Defense Management, The Republic of Indonesia Defense University, Sentul IPSC Area, Tangkil Village, \\ Citeureup District, Bogor, 16810, Indonesia \\ ${ }^{2}$ Department of Disaster Management, The Republic of Indonesia Defense University, Sentul IPSC Area, Tangkil Village, \\ Citeureup District, Bogor, 16810, Indonesia \\ ${ }^{3}$ Department of Defense Management, The Republic of Indonesia Defense University, Sentul IPSC Area, Tangkil Village, \\ Citeureup District, Bogor, 16810, Indonesia
}

\begin{abstract}
The Covid-19 outbreak has affected changes in various sectors of life. With this change, of course, every organization needs new strategies, scenarios and leadership and management patterns to overcome all the uncertainties that occur in the Covid-19 pandemic. Government agencies are required to adapt according to dynamic conditions, and must be sensitive to the dynamics of changes that occur including how the implementation of work from home is carried out. For this reason, this research was carried out with the aim to find out how the implementation of work from home of the Indonesian Migrant Workers Protection Agency (BP2MI) institution in the second year of the Covid-19 pandemic. The research approach used in this research is qualitative methods. The data was obtained through interviews, observations and documentation.
\end{abstract}

KEYWORDS: BP2MI, Covid-19, Indonesia, Migrant Workers, Pandemic, Work from Home,

\section{INTRODUCTION}

The COVID-19 outbreak has affected various sectors of life. The World Health Organization (WHO) in 2020 has declared the Corona virus or Covid-19 as a pandemic. With the emergence of this Covid-19 outbreak, the condition of the economy, business, trade and organization has all changed. With this change, of course, every organization needs new strategies, scenarios and patterns of leadership and management to overcome all the uncertainties that occur during the Covid-19 pandemic [1].

During the current pandemic, government agencies are required to adapt according to dynamic conditions, and must be sensitive to the dynamics of changes that occur. The Covid-19 pandemic has changed many things and demands new arrangements and adaptations of habits in order to live productively and avoid the transmission of Covid-19. The new normal life order policy emerged as a rational calculation of forecasts for national economic conditions, compromise of a long enough time span and understanding that it is very likely that Covid-19 will never disappear from the face of the earth, so that people must explore the possibility of peaceful coexistence [2].

The challenges of the Covid-19 virus are unprecedented due to their impact on key aspects of the organization's existence and survival [3]. The impact of the Covid-19 pandemic is complex and leaves all organizations both private and government in chaos and uncertainty, with no apparent end in sight. Therefore all sectors must make changes in their working systems. Government policies in preventing the spread of the Covid-19 virus have been widely issued which of course has an impact also on service standards in all sectors.

The Covid-19 pandemic is not only damaging the joints of the economy but also the real sector. The implementation of the Activity Restriction system makes most business actors reduce or even close their business activities. Of course, this makes the leaders of an organization twist their brains in order to continue to survive in this uncertain situation. Likewise with the public sector with all system changes in this pandemic.

The implementation of government policies during the Covid-19 pandemic related to the new normal encourages people to remain productive. This of course also changes the systematics of public services in government agencies. This policy is contained in the Circular of the Minister of PANRB No. 67/2020 which is an amendment to Circular No. 58 of 2020 concerning the Work System of State Civil Apparatus Employees (ASN) in the New Normal Order [4]. The Circular contains adjustments to the work system for ASN to maintain the continuity of the implementation of tasks and functions in the administration of government and 


\section{Implementation of Work from Home Institutional of Indonesian Migrant Workers Protection Agency (BP2MI) in the Second Year of the Covid-19 Pandemic towards Society $\mathbf{5 . 0}$}

public services to meet the new normal that is productive and safe from Covid-19 [5]. Bureaucratic changes in government agencies occurred, which were originally carried out normally, and turned to the new normal bureaucratic model. In the work system, there are two systems, namely the Work From Home (WFH) system and still working in the office / Work From Office (WFO) by observing and implementing health protocols.

The implementation of government policies during the pandemic has caused government public services to require employees to work from home so that various public services cannot be provided directly. At the same time, many institutions or institutions have experienced improvements related to information services. Seeing this condition, the government took various steps to adapt to this new normal order.

The Indonesian Migrant Workers Protection Service Agency (BP2MI) as a non-ministerial government agency engaged in the Protection Service of Indonesian Migrant Workers also applies the same related to government policies in the pandemic period. As a follow-up to the Minister of Manpower's Decision on The Temporary Termination of The Placement of Indonesian Migrant Workers and noted the widespread outbreak of the Covid-19 virus as a global health emergency, BP2MI temporarily suspended the Indonesian migrant worker placement (PMI) service in the destination country starting on March 20, 2020. With the temporary suspension, all information and consulting services are carried out online by utilizing information technology. Therefore, all employees need to improve their ability to use digital media, so that new working performance habits are formed so that they remain productive with digital media during the pandemic [6].

The Covid-19 pandemic has changed working conditions in government organizations, including at BP2MI. Circular regarding the rules for the work system of state civil servants in the new normal order issued by the minister for the utilization of the state civil apparatus serves as a guideline regarding changes to the work system in government institutions or institutions in Indonesia. The implementation of the WFH system certainly has an impact on the quality of public service delivery. One example is that public services have become somewhat hampered due to several factors in the service sector that cannot serve the community directly. So public service providers are challenged to always make innovations in providing services so that public services are not hampered, by making a breakthrough in the form of innovations in providing services so that services are not hampered such as providing services through an online system. This is in line with the implementation of e-government, which is an effort from the government in developing electronic-based service delivery by utilizing information technology [7].

The Covid-19 pandemic gave rise to several government policies that must adjust or adapt and respond to changes that occur. Challenges and obstacles in the implementation of bureaucracy are not easy things to overcome. Related human resources or apparatus must remain productive by complying with health protocols. The new normal phase is a new era where people return to activities, work and worship as usual but with new designs or ordinances. This new normal phase should make ASN still have a high performance in serving the community.

BP2MI as a government institution that is at the forefront in providing public services to prospective Indonesian migrant workers must adapt to existing conditions by utilizing information technology. The limited space for movement with the implementation of health protocols, makes information technology a means to support the implementation of service tasks to the community. The implementation of good services and supported by the management of human resources of the apparatus can determine the quality of good public services as well. With the limitations that occur during the pandemic, people must still be given their rights as citizens to continue to be served.

An effective performance management system is essential in times of pandemic. The success of any organization is highly dependent on how to recruit, motivate and retain a high-performing workforce [8]. Performance is the result of work in quality and quantity that can be achieved by an employee in the ability to carry out his duties in accordance with the responsibilities given by his superiors to him [9]. Managing performance so that it runs well must pay attention to important aspects such as the competence of its employees. If an employee is not sure that the given job cannot be achieved, then the expected performance will not be realized.

\section{RESEARCH AND METHODS}

This study uses a qualitative approach with a descriptive method. Data was collected by field observations and in-depth interviews, secondary data in the form of electronic documents and physical documents collected from data collection locations. Furthermore, the collected data is processed by summarizing and selecting things that are considered important and looking for themes and patterns. Presentation of data is done by describing the results of observations and interviews as outlined in the form of a description with narrative text, and supported by documents, photos, and pictures, to draw conclusions

\section{DISCUSSION}

The Covid-19 affects the work system of organizations, both private and government institutions. Government institutions or institutions apply the concept of work from home (WFH) as one of the new normal arrangements. Although it only became 


\section{Implementation of Work from Home Institutional of Indonesian Migrant Workers Protection Agency (BP2MI) in the Second Year of the Covid-19 Pandemic towards Society $\mathbf{5 . 0}$}

popular during a pandemic, WFH has actually been around for quite a while and has been carried out by several professions. With the information technology currently developing, some experts believe that WFH is a future work concept.

WFH when translated literally means working from home without having to come to the office. The application of working at home has the aim of reducing crowds, preventing indirect transmission of Covid-19, reducing employee activities outside the home and maintaining the health of employees and their families. The application of the work from home or WFH system uses online media applications such as Zoom, Google Meet, Whatsapp, Line, Telegram, Google Drive and also the official website of the institution or institution [10]. Online media applications to support public service activities are strongly influenced by the use of data networks, if the network is good and the mastery of the application is also capable then the employee's performance will not experience obstacles and vice versa if the network and the mastery of supporting applications are not supported then the employee's performance will experience obstacles. The implementation of the work from home or WFH system must optimize the development of employee performance.

Referring to the rules from the Ministry of State Apparatus Empowerment regarding changes in the ASN work system during the implementation of activity restrictions during the pandemic, BP2MI also adapted the work system. ASN who are directly related to public services must continue to carry out their activities as usual in the midst of the Covid-19 pandemic. In carrying out public services to the community, BP2MI carries out a scheduling system so that government administration and public services continue to run smoothly. This is done to maintain the performance of government and public services in general. With the new normal order, of course there will be a new pattern in carrying out daily activities without ignoring health protocols. This is done to minimize the spread of the Covid-19 virus.

The physical presence of employees at work is carried out with a strict pattern of protection rules and with the implementation of a schedule for employees to work in the office or at home. ASN of BP2MI must still be active in public service, especially in service to Prospective Indonesian Migrant Workers (CPMI). If an institution stops serving the community, there will be a crisis and chaos [11]. Work from home (WFH) activities depend on the use of information technology as a means and infrastructure for online media applications, such as Zoom, Whatsapp group, Google Meet, Telegram and websites or applications from institutions or institutions. Therefore, employees must be able to master the use of online media applications to support work processes during the pandemic.

In implementing the WFH and WFO systems, one of the things used to assess employee performance is the attendance system. The attendance system that originally used fingerprints has switched to an online attendance system that can be accessed anywhere and anytime. This is because the use of fingerprint attendance accelerates the spread of the Covid-19 virus where employees have to put their fingers on the machine every day when they enter the office and go home from work and take turns. So as a prevention effort, an online attendance system is implemented that can be accessed by each employee wherever they are.

The employee attendance system is often used to ensure the commitment and responsibility of employees to their work to get maximum results and according to the goals that have been set [12]. The attendance system is very important to assess employee performance in terms of employee discipline and responsibility [13]. Employee loyalty and performance is not only determined by how often employees come to the office, adherence to organizational culture is also a consideration.

The application of online attendance through the BP2MI Personnel Information System Application has the benefit of increasing effectiveness and efficiency in the management of its human resources. Therefore, in the implementation of WFH or WFO, each employee must also fill in the e-performance that is adjusted to the main duties and functions of each employee that has been determined. The effectiveness of the implementation of online attendance policies during the pandemic must continue to be improved and adjusted from time to time because the government as a managerial employee / ASN continues to monitor the policies implemented. This application must continue to be improved in accordance with the needs and advances in information technology in accordance with developments.

The definition of absenteeism is an activity carried out by employees to prove that they are present or not present at work in an institution [14]. Attendance itself is related to the discipline of an employee. With online attendance, the recording of an employee's attendance can be seen in real time so that there is no manipulation of employee attendance data. This attendance recording affects the performance allowance system for each employee. Attendance is also used as an evaluation basis to assess employee performance results or performance appraisals in accordance with institutional regulations.

The adjustment of the work system at BP2MI was carried out in order to prevent the spread of the corona virus disease 19. Under the provisions for Activity Restrictions in accordance with the government's appeal, employees were asked to complete a self-assessment to ensure that employees were not infected with the Covid-19 virus. Employees who work in offices are required to run a PCR test with a negative result. In addition, it is prohibited to work in the office for employees who experience symptoms such as fever, cough, runny nose and other symptoms related to Covid-19. Setting the number of employees working in the office is $50 \%$ of the total employees in each unit so that there is always scheduling related to employee attendance at the office. In addition to this, there is an appeal for those who work with the WFO system not to use public transportation to prevent the spread of this virus. 


\section{Implementation of Work from Home Institutional of Indonesian Migrant Workers Protection Agency (BP2MI) in the Second Year of the Covid-19 Pandemic towards Society $\mathbf{5 . 0}$}

The lockdown system at the institution was once carried out when there was an increase in the number of positive cases of the Covid-19 virus that occurred in employees. Lockdown can help prevent the spread of the Covid-19 virus to an area so that people in the area can avoid the rapidly spreading Covid-19 outbreak. Lockdown activities are part of the legislation contained in Law Number 6 of 2018 concerning Health Quarantine. The law discusses health quarantine at the entrance and in the area, carried out through observing diseases and public health risk factors for transportation means, people, goods and or the environment as well as responding to public emergencies in the form of health quarantine measures.

Regarding the obligation to show a negative Covid-19 test to work in the office, the Covid-19 virus examination is carried out in several ways in terms of sensitivity, namely by examining the molecular method, using PCR in the form of immunoglobulin examinations or antigen tests as an initial screening test effort and can be carried out. en masse. The goal is to find out as soon as possible the condition of employees who are positively exposed to the corona virus, so that further isolation efforts can be carried out and effective handling related to this.

To ensure that public services to the community can continue to run effectively, information technology is used to simplify the process. In addition, information to the public through changes in services in accordance with established standards is carried out through publication media so that the public can know and take advantage of these changes safely, quickly and comfortably.

Official activities such as official trips are carried out selectively according to the level of urgency and priority to be carried out by taking into account the applicable regulations. Meetings or meetings as well as coordination between stakeholders are carried out by utilizing the application of information and communication technology or through electronic media. If it is carried out offline at the office, you must pay attention to a safe distance in accordance with health protocols.

At this time related to meeting activities or meetings have been carried out in a hybrid meeting. With hybrid meetings, the concept of meeting is not tied to a specific location. Hybrid meeting means a combination of in-person and virtual, online, or cloud participation. For example, a meeting is attended by several people from the meeting room, while other participants join from home or other locations online [15]. Hybridization is a clash of civilizations which is an approach to creating a new culture as a form of globalization [16]. Almost all sectors have used the hybrid concept in the midst of the pandemic due to the impetus through the rapid growth of technology which is the main factor for hybridization.

With the WFH culture increasingly accustomed to the wider community of life, virtual meetings become one of the activities that can no longer be released Virtual meetings are an ease offered at the time of the pandemic. With the WFH culture increasingly accustomed to the scope of society, virtual meetings with hybrid systems become one of the activities that become solutions. Virtual meetings make the process of discussion, submission of opinions, until the settlement becomes smoother.

As the organizer of the wheels of government, ASN plays an important role in efforts to combat the Covid-19 pandemic. ASN is expected to provide an example of productive and optimal work, while carrying out health protocols in an orderly manner and succeeding the Covid-19 vaccination program nationally. As a public servant, ASN of BP2MI vaccinates in order to provide better services to Indonesian Migrant Workers. This employee vaccination program affects the working system in the new normal order in accordance with the circular of the minister of empowerment of the state apparatus and bureaucratic reform No. $24 / 2021$.

\section{CONCLUSIONS}

The public service system implemented so far certainly has various obstacles and problems. The Covid-19 pandemic has made all sectors in government innovate through digital transformation. The covid pandemic has provided many lessons for us in terms of governance of government bureaucracy. Under any circumstances, the government bureaucracy must remain at the forefront of the implementation of public services to the public. The era of the Covid-19 pandemic makes the implementation of bureaucracy optimize the utilization of information technology.

The utilization of information technology provides positive value in encouraging the successful achievement of the goal of implementing electronic-based government systems (SPBE). Public service innovation must continue to be developed as a step into the era of society 5.0. The concept of Society 5.0 is a human being who can solve various social challenges and problems by utilizing various innovations born in the era of the Industrial Revolution 4.0 and centered on technology [17] This view emphasizes that technology is a means, whereas humans remain the main actors.

\section{RECOMENDATION}

With the rapid and dynamic development of the environment / era of disruption, ASN must be adaptive, changing, and transformative and loyal to Pancasila, NKRI, and the constitution, and serve by maintaining integrity. ASN as a public servant is expected to be able to solve various challenges and social problems that utilize innovations that have been born in the industrial revolution 4.0, so as to encourage the implementation of agile organizational governance to improve organizational performance and productivity processes [18] Bureaucratic society 5.0 will encourage quality public services and improve the integrity and performance of human resources in the future [19]. 


\section{Implementation of Work from Home Institutional of Indonesian Migrant Workers Protection Agency (BP2MI) in the Second Year of the Covid-19 Pandemic towards Society 5.0}

Seeing the above, in the success of a bureaucracy for better organizational governance, it is necessary to increase and improve information technology infrastructure. In running their organization facing this era of disruption, the leadership of an institution must encourage its employees to increase their capacity in mastering information technology-based applications. In addition, employees must continue to innovate in improving public services with new ideas and ideas that can be accepted by the community.

\section{REFERENCES}

1) Esdm. (2021, June 24). Sharing Knowledge: Challenges of HR Management in the Era of the Covid-19 Pandemic. Taken back from https://migas.esdm.go.id/post/read/sharing-knowledge-tantangan-pengelolaan-sdm-di-era-pandemi-covid-19

2) Yulianto, T. (2020, June 28). New Normal: New Order Pattern . Taken back from https://kompaspedia.kompas.id/baca/paparan-topic/normal-baru-pola-live-tatanan-baru

3) Sónia P. Gonçalves, J. V. (2021). COVID-19 and People Management: The View of Human Resource Managers. Administrative Sciences, 1-13.

4) Circular Letter of the Minister for Empowerment of State Apparatus and Bureaucratic Reform Number 67 of 2020 concerning Amendments to Circular Letter of the Minister of Empowerment of State Apparatus and Bureaucratic Reform Number 58 of 2020 concerning Work System of State Civil Apparatus Employees in the New Normal Order

5) Menpan RB. (2020, May 19). ASN Prepares for the New Normal. Taken back from https://www.menpan.go.id/site/berita-terkini/asn-bercepat-menyongsong-tatanan-normal-baru

6) Esthi, R. B. (2020). Human Resources Strategy in the Pandemic and New Normal Periods Through Remote Working, Employee Productivity, and Upskilling for Digital. JPM: JOURNAL OF COMMUNITY SERVICE, 22-24.

7) Inas Tasya Firdaus, M. D. (2021). Digital Bureaucracy Transformation During the Covid-19 Pandemic To Realize the Digitization of the Indonesian Government. Kybernan :Journal of Governance Studies Vol 4 No 2, 226-239.

8) Misna Ariani, I. A. (2021). Employee Performance during the Covid 19 Pandemic: Study at PT. Mulia Jaya Mandiri Balikpapan. Journal of Geoeconomics Volume 12 Number 02, 233-243.

9) Mangkunegara, A. (2017). Company Human Resources Management. Bandung: Rosdakarya Youth.

10) Nadya Safirasari Setiawan, A. R. (2021). The Effect of Work From Home (WFH) on Employee Performance during the COVID-19 Pandemic. Educational: Journal of Educational Sciences, 3229 - 3242.

11) Fitria, N. J. (2020). Implementation of Work From Home and Work From Office with Online Attendance as an Implication of E-Government in the New Normal Period. Civil Service VOL. 14, No.1, 69-84.

12) Subiantoro, S. (2018). Employee Attendance System Design Case Study : Purwodadi District Office. JOURNAL OF SWABUMI, Vol.6 No.2 , 184-189.

13) Safuan, D. R. (2021). Application of an Android-Based Online Attendance System (Case Study at the Regional Government Office of Majalengka Regency, West Java. Journal of Technology and Business Information Systems Vol. 3 No. 1, 267-275.

14) Ristiani, R. (2021). Performance Evaluation in Work Relations During the Covid 19 Pandemic (Methods, Benefits, and Keys to Success). Journal of Secretarial and Management Focal Vol 8 No 1, 1-11.

15) CNN Indonesia. (2021, March 31). Hybrid Meeting to Increase Collaboration and Productivity. Taken back from https://www.cnnindonesia.com/technology/20210331112240-190-624280/hybrid-meeting-to-ingkatkan-kolaborasi-danproductivity

16) H, S. B. (2021). Waiting for "Hybrid Sundries", New Passion After the Pandemic. Taken back from https://lpmopini.online/menanti-serba-serbi-hybrid-gairah-baru-usai-pandemi/

17) 17) Adriel Sebastian S, d. (2021, September 29). The Role of Education in the Development of the Era of Society 5.0. Taken back from https://bpkpenabur.or.id/bekasi/smak-penabur-harapan-indah/berita/berita-lain/peran-dunia-dalamperkembangan-era-society-5-0\#: :text=Oneofthese $\% 20$ one $\% 20$ form $\% 20$ change $\% 20,4.0 \% 20$ and $\% 20$ centred $\% 20 \mathrm{in} \% 2$ Otechnology.

18) Vernanda, R. (2019). Indonesia's Readiness Towards Agile Governance. National Conference on Administrative Sciences, 1-6.

19) Andika Yasa, S. M. (2021). Strengthening Bureaucratic Reform Towards the Era of Society 5.0 in Indonesia. Master of the Journal of Government Science Vol 20 No 1, 27-42. 